\title{
Kocuria spp
}

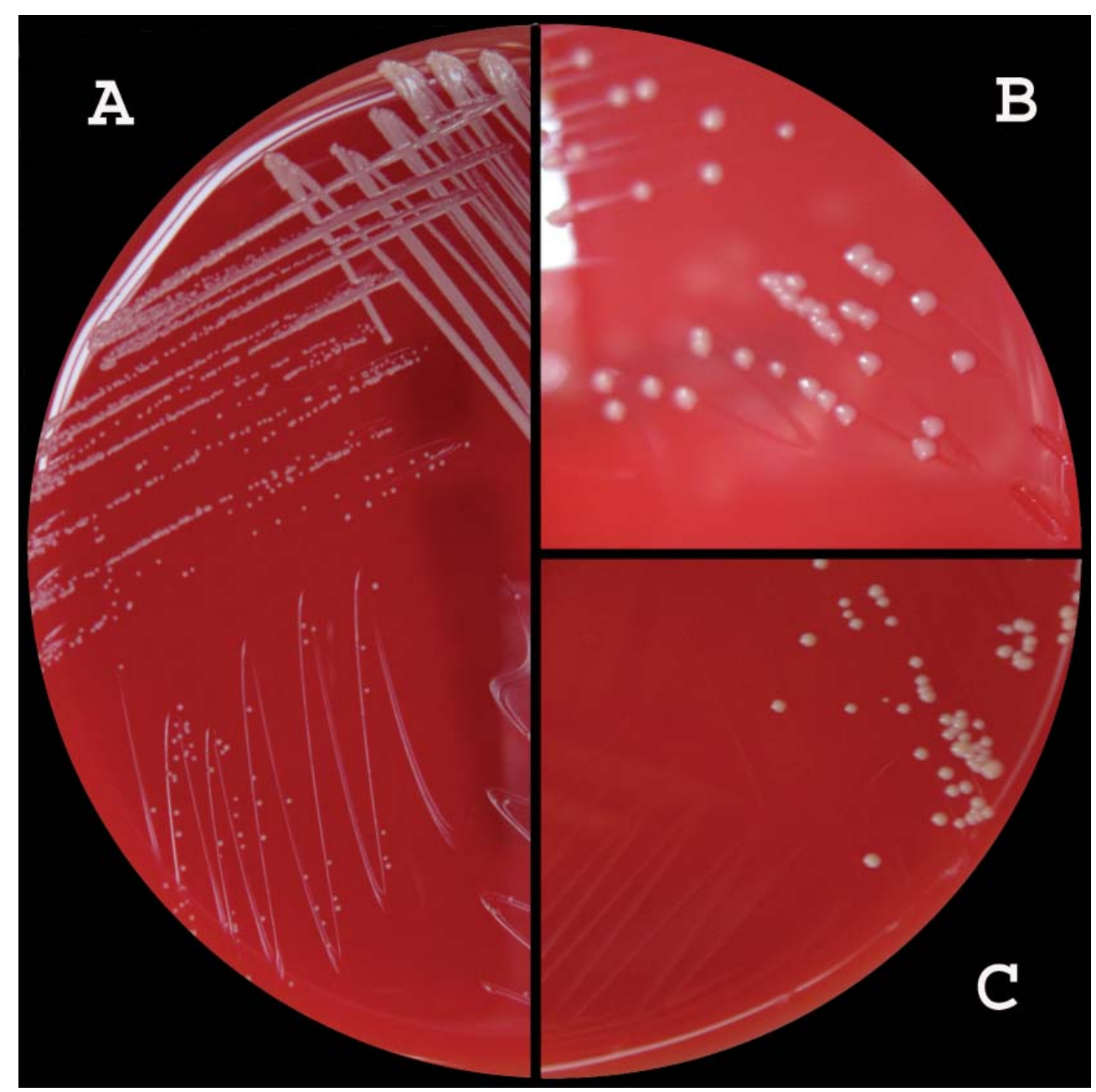

Figura 1. A. Colonias de K. kristinae a las 48 horas de incubación en agar sangre de cordero $5 \%$ en $5 \% \mathrm{CO}_{2}$. B. Detalle de colonias de Staphylococcus coagulasa negativa (S. saprophyticus ATCC BAA-750). C. Detalle de colonias de K. kristinae (ATCC BAA-752). 


\title{
Retrato Microbiológico
}

\section{Kocuria spp}

Las especies del género Kocuria son cocáceas grampositivas de la familia Micrococcaceae. Incluye 17 especies de las cuales la mayoría son aerobias estrictas, con excepción de K. kristinae que es facultativa. Son cocáceas agrupadas en racimos o tétradas, catalasa positiva, coagulasa negativa. Crece en medios habituales, como agar sangre de cordero, como colonias no hemolíticas cremosas, la mayoría de las veces de color blanquecino a amarillento aunque puede haber colonias anaranjadas. Estas características las hacen fácilmente confundibles con Staphylococcus coagulasa negativa. La identificación bioquímica del género y especies es difícil dada la heterogeneidad en la expresión de las pruebas bioquímicas. Algunas especies (K. kristinae, $K$. varians, $K$. rosea) están incluidas en la taxa de los sistemas miniaturizados y automatizados de identificación, aunque hay reportes de errores confundiéndose con especies de Staphylococcus. La diferenciación puede ser hecha por la resistencia de Kocuria spp. a los nitrofuranos y susceptibilidad a bacitracina, aunque estas pruebas no la distinguen del resto de las micrococáceas.

Kocuria spp. es parte de la microbiota de la piel y orofaringe y muchas de las especies se han aislados de muestras de origen ambiental y animal (suelos, agua marina, carnes, pollos). Con la introducción de nuevos sistemas de identificación automatizada ha empezado a ser reconocida, pudiendo antes haber sido informadas como Micrococcus spp. Los casos clínicos de infecciones comprobadas son escasos pero se han descrito en bacteriemias, sepsis asociada a catéter, endocarditis, colecistitis aguda, peritonitis y abscesos, en general en pacientes inmunocomprometidos. Sólo las especies $K$. rosea, $K$. kristinae, $K$. varians, $K$. marina y K. rhizophila han sido descritas en humanos. Es sensible a cefalosporinas, glicopéptidos, aminoglucósidos y tetraciclinas, mostrando una susceptibilidad variable a quinolonas, lincosamidas y cotrimoxazol.

\section{Referencias}

1.- Savini V, Catavitello C, Masciarelli G, Astolfi D, Balbinot A, Bianco A, et al. Drug sensitivity and clinical impact of members of the genus Kocuria. J Med Microbiol 2010; 59: 1395-402.

\author{
Dr. Francisco Silva \\ Unidad Microbiología \\ Servicio de Laboratorio Clínico \\ Hospital Clínico Universidad de Chile. \\ Correspondencia a: \\ Francisco Silva Ojeda \\ fsilva@redclinicauchile.cl
}

